\title{
Difference Study on Relationship Paths of Festival Marketing Activities
}

\author{
Shwu-Ing Wu (Corresponding author) \\ Department of Business Administration, National Chin-Yi University of Technology, \\ Taiwan
}

Tel: 8-86-4-23924505 E-mail: wusi@ncut.edu.tw

Received: Dec. 21, 2016 Accepted: Dec. 26, 2016 Published: May 15, 2017

doi:10.5296/bms.v8i1.11226 URL: https://doi.org/10.5296/bms.v8i1.11226

\begin{abstract}
Different places around the world attract the tourists by festivals and industrial, cultural and spatial characteristics. By festival marketing, they approach the tourists and can influence or change tourists' impression and travel in the destinations. Hence, festival marketing activity becomes the important strategy to trigger regional economic development. However, can festival marketing activities held in the areas comply with the surrounding factors and integrate the factors to become characteristics and attract the tourists? It is the topic of this study which mainly explores the impact of festival marketing, landscape construction and regional characteristics on tourists' value perception and revisit commitment. According to the findings, effect relationship path and relationship intensity of different types of festival marketing activities are different. It means that different areas should hold the unique and appropriate festival marketing activities in order to increase tourists' value perception. It can significantly and positively influence tourists' commitment. In addition, when planning festival marketing, local government and related industries should make sure that the content of festival marketing activities can make tourists happy and to reinforce their revisit commitment.
\end{abstract}

Keywords: Festival marketing, Landscape construction, Regional characteristics 


\section{Introduction}

Festival and tourism are two sides of one body. Festival is the most important part to trigger economic effectiveness of tourism. Therefore, local governments tend to promote the development of tourism business by festival marketing and it becomes fashionable. Since festivals are the rapid and concrete marketing projects and they can attract foreign tourists and create business opportunities, they become the best choice to develop tourism. Therefore, various festivals are the important strategies in different countries to develop tourism and it becomes the most attractive trend of tourism nowadays (Burr, 1997; Cunningham, 1995). However, how to successfully promote festivals is the important issue of different regions. In Taiwan, there are many marketing activities in the name of festival, from International Children's Folklore \& Folkgame Festival, Yilan of northern Taiwan and Pingtung Bluefin Tuna Cultural Festival of southern Taiwan. There are more than 10 festivals in one year. Local governments and the companies invest in manpower and money on these festivals in order to obtain the benefits. Nevertheless, the people have too many choices from these festivals. Hence, how to highlight the characteristics of festivals to be well-known with limited resources becomes particularly important. Besides the promotion of festivals, local landscape construction and regional characteristics are more important and they are the issues which should be explored by local governments and the industries. Thus, they are worthy of further study.

Regional landscape construction includes transportation planning, landscape, infrastructure and natural surrounding which influence tourists' emotional reaction, behavior and decision-making (Zeithaml \& Bitner, 2000). If we can integrate geographic resources, historic culture and traditional skills as unique local features, we will develop the impact and attract the tourists and they are critical factors. Festival marketing activities, landscape construction or regional characteristics should strengthen tourists' value perception by actual experience. Therefore, in travel experience, if regional festival marketing activities, landscape construction and featured culture can meet the tourists' needs, they will enhance their image and value perception and revisit commitment (McLuhan, 2000).

Based on above, this study probes into impact of festival marketing, landscape construction and regional characteristics on tourists' social value, hedonic value and future travel commitment. Although some studies in the past have probed into regional development, few of them conducted diverse in-depth study on previous dimensions. There were rare analysis and comparison on different types of festival marketing activities in different cities to find their difference. Therefore, this study selected two cities in northern Taiwan which are close in location and are highly similar (Taipei City and New Taipei City) as the regions and the targets are different types of festivals held in the cities (New Year Fireworks and The Sky Lantern Festival). The researcher investigated the tourists who have participated in these festivals and analyzed tourists' value perception on different types of festivals and difference of their effect relationship path and intensity. From tourists' perspectives, this study proposed the views and suggestions in order to provide more concrete practical information to help 
local governments and related industries to establish appropriate festival marketing strategies.

\section{Literature Review and Construction of Hypotheses}

\subsection{Relationship between festival Marketing Activities and Tourists' Perceived Value}

Festival marketing means the activities with specific or special themes in specific periods and locations beyond regular activities. The purpose is to attract great number of people by image of festivals. They enhance local economic and business benefits by participants' personal experience and word-of-mouth and strengthen regional development in order to promote the places. In short, festival is the public celebration with themes (Getz, 2005). From perspective of activity content, festival marketing means the special activities including product, service, thought, information and group characteristics (Jackson, 1997). Therefore, festival marketing activities are based on festivals as the themes. It can be one-time or frequent activity and the purpose is to trigger tourists' visit motivation and drive of travel and it encourages tourists to participate in the related activities or have purchase behavior (Veres, Clark \& Golbourne, 2008; Wu, 2016).

Foley \& Mcpherson (2007) proposed that festival marketing activities should find the balance between tourists, local business and local residents' benefits. Hence, there is dynamic relationship and the three parties can be benefited since local festivals can not only attract the tourists, but also be the most direct and concrete promotion channel of local culture. They can specifically present local cultural characteristics (Hinch, 1996). Therefore, marketing of local festivals promotes historic culture and creates tourists' value perception. Local residents obtain benefits by business activities and it helps create regional image and reputation.

Tourists' purposes to participate in festivals are simply to have fun and enhance affection. Holbrook (1994) suggested that people's social value perception is mainly from connection with social group. By interaction with original region, economy, culture and groups of various levels, they develop affection and sense of belonging. From perspective of consumers' behavior, social value is developed when consumers realize that certain product or service matches their or adored reference group. Consumers perceive not only the practical function, but also the symbolic meaning. Their self-value can even be satisfied or presented (Sheth, Newman \& Gross, 1991). Social value is often associated with impact of interpersonal interaction. Thus, when consumers realize that participation in festival marketing activities can be accepted by their or adored reference groups, their behavioral intention will be strengthened (Mort \& Drennan, 2005). Therefore, when people participate in festival marketing activities, they perceive that they have positive interaction with relatives and friends and it enhances their affection, self-image, social position, sense of belonging and social identify. It is social value. Therefore, this study proposes the following hypothesis:

H1: Participation in festival marketing activities significantly and positively enhances tourists' social value perception.

Another purpose to participate in festival marketing activities is to obtain pleasant feelings. 
Therefore, hedonic value developed by festival marketing activities is extremely important. Babin, Darden \& Griffin (1994) suggested that hedonic value is entertainment oriented and it is consumers' multiple feelings and imagination and entertaining evaluation on consumption experience. Thus, hedonic value is personal affection and it is often developed in consumption process. What is perceived by customers is not actual economic benefit and value and it is the relaxing feelings in the experience and the feelings cannot be measured by money (Chaudhuri \& Holbrook, 1996; Babin \& Attaway, 2000). Therefore, in festival marketing activities, if the consumers can obtain positive feelings, aesthetic experience or have dreams come true, it can be called hedonic value (Langrehr, 1991).

Thus, festival marketing information should highlight the pleasure and it helps enhance hedonic value perception. Consumers are attracted by activities and they participate in activities and perceive the advantages of the products. In long term, it constructs regional image and activity identification and further triggers consumers' interest and enhances their participation behavior (Button, 2003). Therefore, festival marketing activities can result in tourists' pleasure by touch and experience and strengthen their positive feelings toward the regions and tourists' hedonic value. Thus, this study develops the following hypothesis:

H2: Participation in festival marketing activities significantly and positively enhances tourists' hedonic value perception

\subsection{Relationship between Landscape Construction and Tourists' Perceived Value}

Natural landscape of travel destinations is one of the incentives for tourists. For instance, in the sites of Queen Stone of Yehliu of Taipei and Yellow Lily of Taimali of Taitung, the magnificent natural landscape leads to tourists' positive image toward the areas and it enhances their revisit intention. Thus, landscape construction becomes the main attraction factor for tourists. Landscape construction quality is the main content of recreational resources. Hence, value of landscape construction for tourists becomes higher.

Festival marketing activities are certainly associated with landscape construction of destinations. Local governments should have long-term planning, business and operational management to integrate festival marketing activities and landscape construction and lead to maximum benefits. Scope of landscape construction is not only the areas of activities and it can be extended to the whole city, including mass transportation, public facilities and related industries. Therefore, complete infrastructure is the key factor of tourists' visit. The role is to transmit the main concept to people by visible landscape design or planning, such as leisure facilities, environmental security and site planning in order to establish people's overall image and influence tourists' emotion and value perception (Beerli \& Martín, 2004).

Beerli \& Martín(2004) suggested five dimensions of landscape construction of travel destinations, including natural and cultural resources, public recreation and facilities, atmosphere, safe environment and tourism resources. They create people's overall perception of environment and tourists' emotion since tourists evaluate the value of destinations by infrastructure and travel quality as the criteria of revisit (Baker, Grewal, Parasuraman \& Voss, 
2002). Hence, landscape construction is the important source of tourists' value perception (Wu, 2016).

Positive spatial environment can result in positive feelings for consumers and upgrade their value perception. It can also influence consumers' views and subjective judgment (Baker et al., 2002). Thus, environmental factors such as natural landscape, historic relics and local characteristics influence tourists' emotion and behavior (Bitner, 1992). Dramaturgical theory suggests that music, lighting, odor, color and decoration in physical environment will enhance or control consumers' behavior (Wu \& Huang, 2015). Consumers' positive interaction with the surrounding positively influences perceived value. It means that positive landscape construction can result in tourists' positive perceived value (Baker, 2006). This study mainly probes into social value perception and hedonic value perception of tourists' perceived value. According to previous perspective, this study proposes the following hypotheses:

H3: Positive landscape construction significantly and positively enhances tourists' social value perception

H4: Positive landscape construction significantly and positively enhances tourists' hedonic value perception

\subsection{Relationship between Regional Characteristics and Tourists' Perceived Value}

Regional characteristics mean the resources which represent local special images, including tangible resources, such as terrain, geology, animals, plants, historic relics and specialties and intangible resources, such as historic events, customs, festivals and stories. It means that in an area with common points, the highlighted image recalls someone who creates characteristics different from other regions (Babin et al., 1994). In Taiwan, natural and human landscapes are complicated and changeable. The country has rich tourism resources and there are different features in different areas which become the important themes of local tourism development. If we can design activities or themes which highlight local characteristics according to specific geographic resources or human activities in different regions to attract the tourists, it will trigger local development.

Baker et al. (2002) suggested that environment influences consumers' views and subjective judgment. Therefore, regional characteristics influence tourists' perception of consumption value (Bitner, Barnes \& Ward, 1992). Natural landscape changes tourists' emotional reaction and their satisfaction with experience. Different environmental attributes will result in different recreational experience. Featured culture created in the regions stimulates tourists' emotional value perception and their behavior (Babin et al., 1994). Hence, unique culture of the regions can establish local image and influence customers' value perception (Booms \& Bitner, 1981; Wu, 2016). Therefore, with more unique regional characteristics, tourists are more likely to visit the places and it enhances tourists' social value and hedonic value. Hence, this study proposes the following hypotheses: 
H5: Regional characteristics significantly and positively enhances tourists' social value perception

H6: Regional characteristics significantly and positively enhances tourists' hedonic value perception

\subsection{Relationship between Tourists'Perceived Value and Commitment}

Commitment is customers' psychological affection, loyalty and identification toward enterprises or brands. It is a kind of emotion of psychological state (Garbarino \& Johnson, 1999); it reflects customers' continuous intention to stay and it guarantees the relationship between customers and enterprises (Hellén \& Sääksjärvi, 2011). When customers identify with specific enterprises or brands, it means the customers have high commitment. In the opposite situation, the commitment is low (Morgan \& Hunt, 1994). Wilson (1995) suggested that commitment means the transaction partners' relationship and desire to continue the relationship in the future. Therefore, commitment is considered as the antecedent of behavior and important source of long-term cooperation (Ranaweera \& Prabhu, 2003).

Gronholdt, Martensen \& Kristensen(2000) proposed four dimensions of tourists' commitment to destinations: revisit intention, recommendation intention, price endurance and construction of word-of-mouth. Participation in festival marketing activities can be measured by 2 dimensions: continuous commitment means tourists' intention of continuous participation in festival marketing activities (White \& Schneider, 2000); emotional commitment means tourists' intention to show close relationship with activities (Harrison-Walker, 2001).

Consumers' perceived value on product will increase their commitment and repurchase intention. It maintains long-term relationship with enterprises (Reichheld \& Sasser Jr., 1990). In study of consumer behavior, perceived value has been validated as the important factor of consumers' behavioral intention (Chen \& Chen, 2010). Therefore, when consumers' perceived value is higher, their commitment to the enterprises will be higher (Ulaga \& Eggert, 2006). Molina, Saura \& García, (2010) demonstrated the positive and significant relationship between consumers' perceived value and commitment. Thus, this study develops the following hypotheses:

H7: Tourists' social value perception significantly and positively enhances tourists' commitment

H8: Tourists' hedonic value perception significantly and positively enhances tourists' commitment

\subsection{Relationship Path Difference of Different Festival Marketing Activities}

In recent years, in different regions of Taiwan, festival marketing models are applied to promote urban characteristics in order to trigger the development of urban economy by festival marketing activities. However, the characteristics of different areas are various, such as 101 New Year Fireworks of Taipei City, The Sky Lantern Festival in Pingxi, New Taipei 


\section{Macrothink

City, Xin She Flower Festival of Taichung and Aboriginal Cherry Blossoms Festival of Sun Moon Lake. Natural environment, cultural history, local food and marketing strategies in different areas are various. Therefore, will festival marketing models of different characteristics, different landscape construction and regional characteristics result in different effects? What is the difference of relationship models of tourists' value perception? It lacks the research. Therefore, this study treats 101 New Year Fireworks of Taipei City and The Sky Lantern Festival in Pingxi of New Taipei City as targets and tries to find if integration of two festival marketing activities and local landscape construction and regional characteristics can stimulate tourists' social value and hedonic value perception and enhance commitment. By festival marketing activities of two cities which have nearly no boundary, this study explores the difference and similarity and proposes the following hypothesis:

H9: Intensity of relationship paths of different types of festival marketing activities is significantly different

\section{Research Design}

\subsection{Research Structure}

Based on previous literature review, this study constructed hypotheses and research framework. Through qualitative research, questionnaire design and sampling survey and analysis, it validates hypotheses and conceptual models proposed. Research framework is shown in Figure 1.

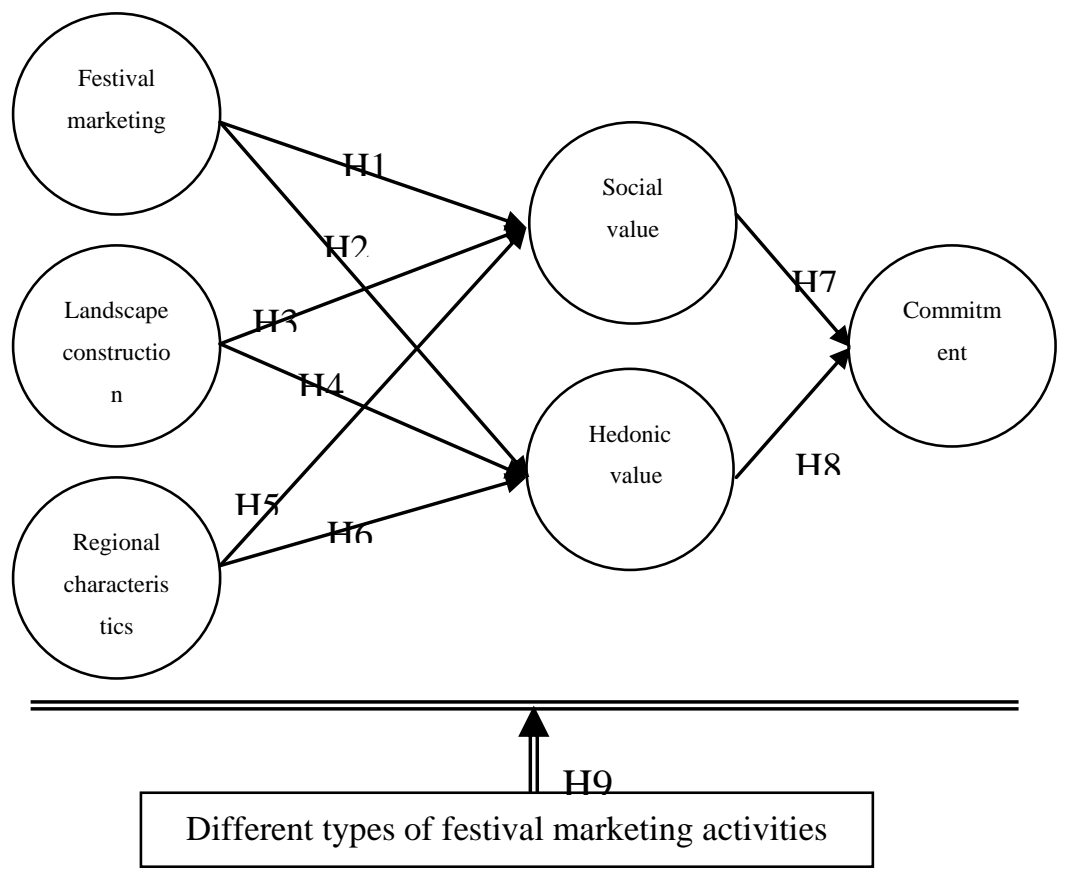

Figure 1. Research

\subsection{Questionnaire Design}

This study first collected related theories and literatures as reference of research framework 
and designed the draft of questionnaire. By questionnaire survey, it collected and analyzed primary data. Questionnaire includes 7 parts: Part 1 is festival marketing, including 5 items, Part 2 is landscape construction, including 5 items, Part 3 is regional characteristics, including 5 items, Part 4 is social value, including 4 items, Part 5 is hedonic value, including 5 items and Part 6 is commitment, including 5 items. The previous scales are based on Likert 7-point scale. As to scoring, it is from "strongly disagree" (1) to "strongly agree" (7). Part 7 is subjects' background information, including 9 items. It is measured by nominal scale.

\subsection{Pretest and Pilot}

Before distributing formal questionnaires, by pretest and pilot, this study modified questionnaire. As to pretest, by convenience sampling, it selected 30 tourists who have participated in one of the previous festival marketing activities and conducted in-depth interview. This study then modified the items with unclear meanings. By modified questionnaires, this study selected 80 subjects with convenience sampling for pilot and conducted reliability and validity analysis. According to result, Cronbach $\alpha$ of dimensions meet the standard (>0.7) (Nunnally, 1978), item to total correlation coefficients are higher than 0.5 (Kerlinger, 1978). It means that reliability of dimensions are good. Based on result of EFA, eigenvalues of dimensions are higher than 1 and cumulative explained variation are higher than 0.5. Factor loading of variables are higher than 0.5. Hence, the dimensions have convergent validity (Kaiser, 1958). This questionnaire is applied for the following formal survey.

\section{Data Analysis}

\subsection{Sample Structure}

This study treated the tourists who have participated in one of the previous festival marketing activities as subjects of sampling. Convenience sampling survey was conducted by interviewers' distribution of questionnaires. 330 questionnaires were distributed. After deleting invalid questionnaires, this study obtained 300 valid ones. Valid return rate is 90.91\%. Based on analysis of samples, males are $37.3 \%$ and females are $62.7 \%$. As to age, most of them are aged 25 34 and percentage is 30.3\%. The second is aged 15 24 and percentage is $26.3 \%$. As to residential area, central Taiwan is the most and percentage is $52 \%$ and the second is northern Taiwan and percentage is $39 \%$. As to educational level, university/college is the most and percentage is 68\%. The second is senior high school (vocational school) and percentage is $21 \%$. Regarding occupation, service industry is the most and percentage is $32.7 \%$. The second is student and percentage is $15.7 \%$. As to average monthly incomes, NT $\$ 10,001 \sim \mathrm{NT} \$ 30,000$ is the most and percentage is $33.3 \%$. The second is NT $\$ 30,001-\mathrm{NT} \$ 50,000$ and percentage is $32.3 \%$. As to average visit frequency in the city, once in less than half year is the most and percentage is $40.7 \%$ and the second is once in a year and percentage is $23 \%$. 


\subsection{Reliability and Validity Analysis}

This study conducted reliability and validity analysis on 300 valid questionnaires. According to Nunnally (1978), Cronbach $\alpha$ should be at least 0.7 . Kerlinger (1978) proposed that item to total correlation coefficients should be higher than 0.5 . In this study, Cronbach $\alpha$ of dimensions and correlation coefficients meet the standard. Therefore, total reliability of questionnaire is good. In addition, according to Kaiser (1958), eigenvalues extracted by factor analysis must be higher than 1. Factor loading of variables in dimensions must be higher than 0.5 and cumulative explained variation must be higher than 0.5 . Thus, in this study, convergent validity of questionnaire is good (see Table 1).

In addition, scale of questionnaire is based on domestic and foreign related literatures and scales as the draft. The researcher discussed with scholars, experts and tourists and modified the questionnaire to establish the pilot items. Finally, by pilot, it decided the formal scale of questionnaire. It demonstrates the content validity of questionnaire. This study developed research framework and model by theories and empirical studies proposed by experts and scholars. Thus, it has nomological validity.

Table 1. Reliability and validity analysis of formal questionnaire

\begin{tabular}{|c|c|c|c|c|c|c|}
\hline Name of factor & Mean & $\begin{array}{c}\text { Item to total } \\
\text { correlation } \\
\text { coefficient }\end{array}$ & $\begin{array}{c}\text { Factor } \\
\text { loadings }\end{array}$ & Eigenvalue & $\begin{array}{c}\text { Cumulative } \\
\text { explained } \\
\text { variation \% }\end{array}$ & $\begin{array}{c}\text { Cronbach } \alpha \\
\text { value }\end{array}$ \\
\hline \multicolumn{7}{|l|}{ Festival marketing } \\
\hline It is unique & 5.93 & 0.833 & 0.903 & \multirow{5}{*}{3.579} & \multirow{5}{*}{71.579} & \multirow{5}{*}{0.900} \\
\hline It is impressive & 5.93 & 0.790 & 0.875 & & & \\
\hline Content is rich & 5.79 & 0.774 & 0.864 & & & \\
\hline It benefits the business district in the surrounding & 6.06 & 0.731 & 0.829 & & & \\
\hline It has cultural characteristics & 5.84 & 0.631 & 0.750 & & & \\
\hline \multicolumn{7}{|l|}{ Landscape construction } \\
\hline Landscape is well maintained & 5.12 & 0.670 & 0.780 & \multirow{5}{*}{3.496} & \multirow{5}{*}{69.913} & \multirow{5}{*}{0.891} \\
\hline Unique landscape & 5.41 & 0.627 & 0.741 & & & \\
\hline Excellent quality of public construction & 5.43 & 0.795 & 0.884 & & & \\
\hline Good urban planning & 5.45 & 0.793 & 0.886 & & & \\
\hline Good facility planning & 5.43 & 0.788 & 0.878 & & & \\
\hline \multicolumn{7}{|l|}{ Regional characteristics } \\
\hline Historic interests & 5.49 & 0.559 & 0.700 & \multirow{5}{*}{3.214} & \multirow{5}{*}{64.280} & \multirow{5}{*}{0.859} \\
\hline Well-known landmark & 5.79 & 0.621 & 0.754 & & & \\
\hline Featured food & 5.49 & 0.767 & 0.872 & & & \\
\hline Featured souvenirs & 5.42 & 0.782 & 0.883 & & & \\
\hline Design which does not exist in other cities & 5.47 & 0.652 & 0.785 & & & \\
\hline \multicolumn{7}{|l|}{ Social value } \\
\hline The activity is valuable & 5.54 & 0.650 & 0.787 & \multirow{4}{*}{3.059} & \multirow{4}{*}{76.476} & \multirow{4}{*}{0.896} \\
\hline The activity can enhance interpersonal interaction & 5.81 & 0.840 & 0.926 & & & \\
\hline $\begin{array}{l}\text { The activity can reinforce relationship with } \\
\text { relatives and friends }\end{array}$ & 5.87 & 0.836 & 0.923 & & & \\
\hline The activity can improve interpersonal relationship & 5.62 & 0.734 & 0.855 & & & \\
\hline \multicolumn{7}{|l|}{ Hedonic value } \\
\hline The activity is pleasant & 5.85 & 0.763 & 0.849 & \multirow{3}{*}{3.851} & \multirow{3}{*}{77.018} & \multirow{3}{*}{0.925} \\
\hline The activity is interesting & 5.82 & 0.797 & 0.873 & & & \\
\hline The activity is creative & 5.77 & 0.802 & 0.876 & & & \\
\hline
\end{tabular}




\begin{tabular}{|c|c|c|c|c|c|c|}
\hline The activity is aesthetic & 5.92 & 0.824 & 0.891 & & & \\
\hline The activity is joyful & 5.87 & 0.838 & 0.899 & & & \\
\hline \multicolumn{7}{|l|}{ Commitment } \\
\hline I will re-participate in the activity & 5.48 & 0.789 & 0.875 & \multirow{5}{*}{3.684} & \multirow{5}{*}{73.685} & \multirow{5}{*}{0.911} \\
\hline I recommend the activity to others & 5.49 & 0.798 & 0.878 & & & \\
\hline I will treat the area as the priority & 5.55 & 0.774 & 0.859 & & & \\
\hline I will participate in different activities in the area & 5.10 & 0.764 & 0.851 & & & \\
\hline I will travel in the area & 5.41 & 0.738 & 0.828 & & & \\
\hline
\end{tabular}

\section{$4.3 C F A$}

In order to validate and measure efficiency of dimensions, this study conducted CFA on measurement models of festival marketing, landscape construction, regional characteristics, social value, hedonic value and commitment by AMOS. According to precise principle, fitness measures of model should be below: ratio of chi-square value and freedom is less than 3(Carmines \&McIver, 1981), RMSEA is lower than 0.05 and GFI, AGFI, NFI, RFI and CFI are higher than 0.9 (Bagozzi \& Yi, 1988; Joreskog \& Sorbom, 1989). The result shows fitness measures of model: $\chi 2 / \mathrm{df}$ is 1.699 , RMSEA is 0.048, GFI is 0.836, AGFI is 0.752, NFI is 0.892 , RFI is 0.847 and CFI is 0.951 . The previous outcomes mostly match or are close to the standard. Therefore, the model is acceptable and the measures have construct validity and measurement efficiency.

\subsection{Analysis of Competing Model}

According to category of festival marketing activities, clusters of this study are $101 \mathrm{New}$ Year Fireworks of Taipei City (150 people) and Pingxi Sky Lantern Festival of New Taipei City (150 people). By AMOS, it conducts analysis of competing model to compare correlation paths and relationship intensity of models in different categories of festival marketing activities. Analytical result demonstrates that among fitness measures of competing model, $\chi 2$ /df is 1.930 , RMSEA is 0.056 , GFI is 0.809 , AGFI is 0.730 , NFI is 0.868 , RFI is 0.826 and CFI is 0.930 . They mostly match or are close to the principle of good model. Hence, in this study, fitness of competing model is good and it shows that the model is acceptable.

\subsection{Comparison of Model Paths of Two Clusters}

According to path analysis of dimensions of competing model, relationship paths of two clusters are different:

Festival marketing of 101 New Year Fireworks and Pingxi Sky Lantern Festival positively and significantly influences social value and hedonic value. The result supports $\mathrm{H} 1$ and $\mathrm{H} 2$.

Landscape construction in the areas of two festivals does not significantly influence social value. The result does not support H3. Landscape construction of $101 \mathrm{New}$ Year Fireworks positively and significantly influences hedonic value. However, landscape construction of Pingxi Sky Lantern Festival does not significantly influence hedonic value. The result partially supports $\mathrm{H} 4$. 
Regional characteristics of 101 New Year Fireworks and The Sky Lantern Festival in Pingxi positively and significantly influence social value. The result supports $\mathrm{H} 5$; regional characteristics of Pingxi Sky Lantern Festival positively and significantly influence hedonic value. Regional characteristics of 101 New Year Fireworks d not significantly influence hedonic value. The result partially supports H6.

Tourists' social value perception of Pingxi Sky Lantern Festival positively and significantly influences commitment. Tourists' social value perception of 101 New Year Fireworks does not significantly influence commitment. The result partially supports H7; finally, the tourists' hedonic value perception of 101 New Year Fireworks and Pingxi Sky Lantern Festival significantly and positively influences commitment. The result supports H8. (see Table 2)

Table 2. Comparison of relationship paths between two festival marketing activities

\begin{tabular}{|c|c|c|c|}
\hline \multirow{2}{*}{ Relationship Path } & \multicolumn{2}{|c|}{ Standardized Regression Weights } & \multirow{2}{*}{ T-test } \\
\hline & $\begin{array}{c}101 \text { New Year } \\
\text { Fireworks (150) }\end{array}$ & $\begin{array}{l}\text { Pingxi Sky Lantern } \\
\text { Festival (150) }\end{array}$ & \\
\hline $\begin{array}{l}\text { H1: Festival marketing } \\
\quad \rightarrow \text { Social value }\end{array}$ & $0.231 * *$ & $0.722 * * *$ & 2.568* \\
\hline $\begin{array}{c}\text { H2: Festival marketing } \\
\quad \rightarrow \text { Hedonic value }\end{array}$ & $0.552 * * *$ & $0.671 * * *$ & 0.177 \\
\hline $\begin{aligned} \text { H3: Landscape construction } \\
\\
\quad \rightarrow \text { Social value }\end{aligned}$ & 0.077 & -0.041 & -0.673 \\
\hline $\begin{aligned} \text { H4: Landscape construction } \\
\\
\quad \rightarrow \text { Hedonic value }\end{aligned}$ & $0.295^{*}$ & 0.004 & -1.738 \\
\hline $\begin{aligned} \text { H5: } & \text { Regional characteristics } \\
& \rightarrow \text { Social value }\end{aligned}$ & $0.433 *$ & $0.190 *$ & -1.929 \\
\hline $\begin{aligned} \text { H6: Regional characteristics } \\
\\
\quad \rightarrow \text { Hedonic value }\end{aligned}$ & 0.119 & $0.204 *$ & -0.013 \\
\hline $\begin{aligned} \text { H7: Social value } \\
\\
\quad \rightarrow \text { Commitment }\end{aligned}$ & -0.176 & $0.308 *$ & $3.071 * *$ \\
\hline $\begin{aligned} \text { H8: Hedonic value } \\
\quad \rightarrow \text { Commitment }\end{aligned}$ & $0.739 * * *$ & $0.470 * * *$ & -1.832 \\
\hline
\end{tabular}


$*: \mathrm{P}<0.05 ; * *: \mathrm{P}<0.01 ; * * *: \mathrm{P}<0.001$

After comparing intensity of relationship paths of different festival marketing activities, we realize that,

1) Relationship paths of "festival marketing" on "social value" of 101 New Year Fireworks and Pingxi Sky Lantern Festival are significantly different $(\mathrm{t}=2.568 *)$. Impact intensity of the relationship path of Pingxi Sky Lantern Festival is more significant (0.722). It shows that tourists tend to find that Pingxi Sky Lantern Festival can enhance their interpersonal relationship and interaction.

2) Relationship paths of tourists" "social value" perception on their "commitment" of 101 New Year Fireworks and Pingxi Sky Lantern Festival are significantly different $\left(\mathrm{t}=3.071^{* *}\right)$. Impact intensity of the said relationship path of Pingxi Sky Lantern Festival is more significant $(0.308)$. It shows that when the tourists perceive that festival marketing activities can reinforce their interpersonal relationship and interaction, they will be more likely to have revisit commitment.

Based on above, after comparing relationship models of different festival marketing activities, we realize that intensity of two relationship paths is significantly different. Hence, H9 is partially supported.

\section{Conclusion and Suggestions}

\subsection{Conclusion}

From tourists' perspectives, this study probes into difference and similarity of effect relationship models of festival marketing activities of 101 New Year Fireworks of Taipei City and Pingxi Sky Lantern Festival of New Taipei City in Taiwan. By empirical study, the researcher explores the impact of festival marketing, landscape construction and regional characteristics on tourists' perceived social value, hedonic value and commitment and this study establishes correlation model and comparative analysis. It develops efficient measures with academic and practical values. According to analysis of competing model,

1) Impact of festival marketing on tourists' social value and hedonic value perception:

101 New Year Fireworks and The Sky Lantern Festival in Pingxi significantly and positively influence tourists' perception of social value and hedonic value. The result matches the concept proposed by Janiskee (1996) and Long \& Perdue (1990). It means that by promotion of festival marketing activities, it not only draws the tourists' attention and exposes the region, but also satisfies the tourists' feelings and pleasure. Thus, they are popular with tourists. In addition, since 101 New Year Fireworks and Pingxi Sky Lantern Festival are well-known festivals in Taiwan, they can trigger the tourists' preference and interest. It enhances tourists' self-identification, interpersonal interaction and happiness. The tourists thus have positive memory. It demonstrates that festival marketing positively reinforces tourists' social value and hedonic value and it is the key to attract the tourists. 
2) Impact of landscape construction in the area of festival on tourists' social value and hedonic value perception:

Landscape construction of 101 New Year Fireworks held in Taipei City and Pingxi Sky Lantern Festival in New Taipei City does not significantly influence tourists' social value perception. Therefore, as to social value, tourists pay more attention to content of festival marketing activities instead of the landscape and facility of the places. Therefore, landscape and facilities of the places are not the key factors of tourists' social value perception. It is the important finding of this study.

In addition, landscape construction of 101 New Year Fireworks in Taipei City significantly and positively influences tourists' hedonic value perception. The result matches the concept proposed by $\mathrm{Wu} \&$ Huang (2015) and Baker (2006). Thus, well-known landscape construction or the landmark "Taipei 101"can actually trigger tourists' hedonic value perception. With live atmosphere, decoration of the environment, facilities and richness of fireworks, tourists can obtain profound visual perception and hearing and be pleasant. They thus have positive impression and evaluation on overall environment and create better perception of hedonic value. Therefore, unique and well-known landscape construction is relatively important for tourists' hedonic value.

However, landscape construction of The Sky Lantern Festival in Pingxi in New Taipei City is not as well-known as Taipei 101 and it does not have significant impact on tourists' hedonic value. It demonstrates that famous landscape construction or landmark is critical to reinforce tourists' hedonic value. In addition, convenience of transportation in landscape construction is the key. Taipei 101 is in downtown and more accessible, whereas Pingxi of New Taipei City is located in remote mountain area. On the holidays, it is crowded and there is traffic jam which causes negative image and complaints. Therefore, it lowers tourists' hedonic value.

3) Impact of regional characteristics on tourists' social value and hedonic value perception:

Regional characteristics of 101 New Year Fireworks and Pingxi Sky Lantern Festival significantly and positively influence tourists' social value perception. The result is consistent with concepts of Babin et al. (1994) and Baker et al. (2002). It means that local unique culture can be attractive for tourists and increase their identification and sense of belonging. It reinforces interaction with relatives and friends and the affection.

In addition, regional characteristics of Pingxi Sky Lantern Festival significantly and positively influence tourists' hedonic value. The result matches the concepts of Booms \& Bitner (1981) and Bitner, Barnes \& Ward (1992). In Pingxi of New Taipei City, tourists can experience the playfulness of sky lantern. Besides, the waterfall in the neighborhood, nostalgia of railway and the old street with local human characteristics are attractive for tourists who can reinforce hedonic value.

However, regional characteristics of 101 New Year Fireworks do not significantly influence tourists' hedonic value. It demonstrates that tourists pay more attention to content and 
richness of New Year Fireworks instead of regional characteristics. Furthermore, since the fireworks are held in downtown and it is crowded in new year's eve and there is traffic jam, it lowers tourists' hedonic feelings.

4) Impact of tourists' social value and hedonic value perception on commitment:

Tourists' social value perception of Pingxi Sky Lantern Festival of New Taipei City significantly and positively influences commitment. The result matches concepts of Chen \& Chen (2010) and Reichheld \& Sasser Jr. (1990). It means that by participating in The Sky Lantern Festival in Pingxi, they enhance interaction and have the intention of positive word-of-mouth to recommend it to others or have revisit commitment.

However, tourists' social value perception of 101 New Year Fireworks in Taipei City does not significantly influence commitment. The traffic jam and crowdedness of $101 \mathrm{New}$ Year Fireworks in Taipei City might be the reasons which lower the tourists' revisit intention. In addition, 101 New Year Fireworks are live TV show and it also reduces the tourists' revisit intention.

In addition, tourists' hedonic value perception of 101 New Year Fireworks and Pingxi Sky Lantern Festival significantly and positively influence commitment. The result matches the concepts of Ulaga \& Eggert (2006) and Molina, Saura \& García (2010). It means that when tourists realize that festivals result in pleasure and playfulness, it will enhance their preference to the activity and revisit intention. Thus, commitment is strengthened.

(1) According to comparison of relationship models of different festivals:

a. As to impact intensity of festival marketing on tourists' social value, effect of Pingxi Sky Lantern Festival is more significant than 101 New Year Fireworks. It shows that the featured activity of a small town is more likely to trigger interpersonal affection.

b. As to impact intensity of tourists' social value perception on commitment, effect of Pingxi Sky Lantern Festival is also more powerful than 101 New Year Fireworks. Therefore, affective interaction of featured activity experience in small town can further enhance tourists' feelings and enhance revisit intention.

c. As to impact intensity of festival marketing on tourists' hedonic value, two festival marketing activities are influential. It means that tourists' participation in festival marketing activities can effectively reinforce their hedonic value. Therefore, hedonic value is the critical motive of tourists' participation in festival marketing activity and it is the key for activity hosts.

\subsection{Managerial Implications}

According to empirical analysis, this study explores tourists' perception of festival marketing activities and probes into impact and correlation of landscape construction and regional characteristics on tourists' social value, hedonic value and commitment. The research finding can serve as important reference for planning of festival marketing activities in different 
regions, as follows:

(1) Impact of festival marketing is the most powerful among three independent variables. Therefore, festival marketing is the necessary tool in local marketing strategy. We suggest that different regions should carefully plan and design festival marketing activities which should present local traditional culture or local characteristics. The event which combines local featured human resources and cultural assets can not only reinforce local tourism image and local industry, but also provide job opportunities for local residents. It preserves cultural tradition, creates local image, constructs community, strengthens local vitality and reputation and accomplishes the purpose to promote the areas.

(2) Regional characteristics are the most significant factor in festival marketing which attracts the tourists' attention. They include local historic relics, humanity, landscape and customs. Without regional characteristics such as local rich human and attractive landscape, it is not easy to attract and touch the tourists. Therefore, using local cultural resources, protecting local culture, valuing tourism quality and establishing unique tourism style are the keys of festival marketing activities.

(3) In comparison to social value, tourists pay more attention to the upgrading of hedonic value. Therefore, festival marketing activities in different areas should be based on tourists' hedonic experience in the travel, such as increasing handmade experience or interesting competitions. By personal experience, tourists have fun in the activities and perceive the festival atmosphere. In addition, hedonic value can trigger tourists' positive emotion. They thus have identification and pleasant travel experience and further develop higher satisfaction and trust. Tourists have more commitment to the activity.

(4) The ultimate purpose of festival marketing is to obtain the tourists' commitment. Therefore, how to create tourists' commitment is the important issue for the activity hosts. It is extremely critical to reinforce tourists' revisit intention and recommendation to others by satisfying their diverse demands since tourists' positive word-of-mouth is more effective than marketing strategy controlled by enterprises. It can serve as criterion for potential tourists and reduce risk and uncertainty to increase new customers and bring more potential customers and local business opportunities.

\subsection{Research Limitations and Suggestions for Future Suggestions}

(1) Upon empirical result, conceptual framework of this study can indicate new academic point as reference for future research. However, populations in this study are the tourists who have only participated in festival marketing of 101 New Year Fireworks of Taipei City or Pingxi Sky Lantern Festival of New Taipei City. Thus, this study has discovered some principles and difference; nevertheless, regional characteristics and human customs are different, they might not be generalized to different types of city or area. We suggest that future researchers can explore the marketing activities of different types of events held in various regions and probe into tourists' perception difference in different cities or activities and realize the effect of the said festival marketing. 
(2) By competing model, this study compares relationship models of landscape construction, regional characteristics, social value, hedonic value and commitment of two festival marketing activities. We suggest that future researchers can include other related variables to explore the issue related to urban tourism industry in order to enrich the research dimensions.

\section{References}

Babin, B. J., \& Attaway, J. S. (2000). Atmospheric affect as a tool for creating value and gaining share of customer. Journal of Business Research, 49, 91-99. http://dx.doi.org/10.1016/S0148-2963(99)00011-9

Babin, B. J., Darden, W. R., \& Griffin M. (1994). Measuring hedonic and utilitarian shopping value. Journal of Consumer Research, 20, 644-656. http://dx.doi.org/10.1086/209376

Bagozzi, R. P., \& Yi, Y. (1988). On the evaluation of structural equation models. Academic of Marketing Science, 16(1), 76-94.

Baker, J., Grewal, D., \& Parasuraman, A., \& Voss, G. B. (2002). The influence of multiple store environment cues on perceived merchandise value and patronage intentions. Journal of Marketing, 66(2), 120-141. http://dx.doi.org/10.1509/jmkg.66.2.120.18470

Baker, S. M. (2006). Consumer normalcy: Understanding the value of shopping through narratives of consumers with visual impairments. Journal of Retailing, 82(1), 37-50. http://dx.doi.org/10.1016/j.jretai.2005.11.003

Beerli, A., \& Martín, J. D. (2004). Factors influencing destination image. Annals of Tourism Research, 31(3), 657-681. http://dx.doi.org/10.1016/j.annals.2004.01.010

Bitner, M. J. (1992). Servicescapes: Impact of physical surroundings on customers and employees. Journal of Marketing, 56, 57-71. http://dx.doi.org/10.2307/1252042

Bitner, M. J., Barnes, J., \& Ward, J. C. (1992). Measuring the prototypically and meaning of retail environments. Journal of Retailing, 68(3), 192-220.

Booms, B. H., \& Bitner, M. J. (1981 ). Marketing strategies and organization structures for service firms. In Donnelly, J. H., \& George, W. R. (Eds.), Marketing of Services (pp. 47-51). Conference Proceedings: American Marketing Association, Chicago, IL.

Burr, S. T. (1997). Love thy neighbor and prosper community festivals and events. Parks \& Recreation, 32(9), 106-118.

Button, J. (2003). Events that build brands. Marketing Magazine, 108, 34.

Carmines, E. G., \& McIver, J. P. (1981). Analyzing models with unobserved variables: Analysis of covariance structures. In G. W. Bohrnstedt \& E. F. Borgatta (Eds.), Social measurement: Current issues (pp.65-115). Beverly Hills, CA: Sage Publications.

Chaudhuri, A., \& Holbrook, M. B. (1996). The chain of effects from brand trust and brand affect to brand performance: The role of brand loyalty. Journal of Marketing, 65(2), 81-93. 
http://dx.doi.org/10.1509/jmkg.65.2.81.18255

Chen, C. F., \& Chen, F. S. (2010). Experience quality, perceived value, satisfaction and behavioral intentions for heritage tourists. Tourism Management, 31(1), 29-35. http://dx.doi.org/ 10.1016/j.tourman.2009.02.008

Cunningham, H. (1995). Event marketing: State of the industry and research agenda. Festival $\begin{array}{llll}\text { Management } \quad \text { Event } \quad \text { Tourism, } & \text { 2(3/4), }\end{array}$ http://dx.doi.org/10.3727/106527095792315521

Foley, M., \& Mcpherson, G. (2007). Glasgow's winter festival: Can cultural leadership serve the common good? Manage Leisure, 12, 143-156. http://dx.doi.org/10.1080/13606710701339330

Garbarino, E., \& Johnson, S. M. (1999). The different roles of satisfaction, trust and commitment in customer relationships. Journal of Marketing, 63(2), 70-87. http://dx.doi.org/10.2307/1251946

Getz, D. (2005). Event Management and Event Tourism. New York: Cognizant Communication Corporation.

Gronholdt, L., Martensen, A., \& Kristensen, K. (2000). The relationship between customer satisfaction and loyalty: Cross-industry differences. Total Quality Management, 11, 509-514. http://dx.doi.org/ 10.1080/09544120050007823

Harrell, G. D., Hutt, M. D., \& Anderson, J. C. (1980). Path analysis of buyer behavior under conditions of crowding. Journal of Marketing Research, 17, 45-51. http://dx.doi.org/10.2307/3151115

Harrison-Walker, L. J. (2001). The measurement of word-of-mouth communication and an investigation of service quality and customer commitment as potential antecedents. Journal of Service Research, 4(1), 60-75. http://dx.doi.org/ 10.1177/109467050141006

Hellén, K., \& Sääksjärvi, M. (2011). Happiness as a predictor of service quality and commitment for Utilitarian and hedonic Services. Psychology \& Marketing, 28(9), 934-957. http://dx.doi.org/10.1002/mar.20420

Hinch, T. D. (1996). Urban tourism : Perspectives on sustainability. Sustainable Tourism, 4(2), 95-100.

Holbrook, M. B. (1994). The nature of customer value: An axiology of service in the consumption experience. In R. T. Rust, \& R. L. Oliver (Eds.), Service quality: New direction in theory and practice (pp. 21-71). Thousand Oaks, CA: Sage publication. http://dx.doi.org/10.4135/9781452229102.n2

Jackson, R. (1997). Marketing special event fit in the 21th century. Champaign, IL: Sagamore Pub. 
Joreskog, K. G., \& Sorbom, D. (1989). LISREL 7 user's reference guide. Chicago, IL: Scientific Software.

Kaiser, H. F. (1958). The varimax criterion for analytic rotation in factor analysis. Psychometrika, 23(3), 187-200. http://dx.doi.org/10.1007/BF02289233

Kerlinger, F. N. (1978). Foundation of behavioral research. New York, NY: McGraw-Hill.

Langrehr, F. W. (1991). Retail shopping mall semiotics and hedonic consumption. Advances in Consumer Research, 18(1), 428-433.

Long, P. T., \& Perdue, R. R. (1990). The economic impact of rural festivals and special events: Assessing the special distribution of expenditures. Journal of Travel Research, 28(4), 10-14. http://dx.doi.org/10.1177/004728759002800403

McLuhan, R. (2000). Go live with a big brand experience. Marketing, 26, 45-46.

Molina, M. E. R., Saura, I. G., \& García, H. C. (2010). The moderating role of age on the relationship between perceived value, retail ICT and customer loyalty. CEDE, 43, 65-91.

Morgan, R. M., \& Hunt, S. D. (1994). The commitment-trust theory of relationship marketing. Journal of Marketing, 58(3), 20-38.

Mort, G. S., \& Drennan, J. (2005). Marketing m-services: Establishing a usage benefit typology related to mobile user characteristics. The Journal of Database Marketing \& $\begin{array}{llll}\text { Customer Strategy } & \text { Management, } & \text { 327-341. }\end{array}$ http://dx.doi.org/10.1057/palgrave.dbm.3240269

Nunnally, J. C. (1978). Psychometric theory. New York, NY: McGraw-Hill.

Ranaweera, C., \& Prabhu, J. (2003). On the relative importance of customer satisfaction and trust as retention and positive word of mouth. Journal of Targeting, Measurement and Analysis for Marketing, 12(1), 82-90. http://dx.doi.org/10.1057/palgrave.jt.5740100

Reichheld, F. P., \& Sasser Jr., W. E. (1990). Zero defeciions: Quoliiy comes to services. Harvard Business Review, 68(5), 105-111.

Sheth, J. N., Newman, B. I. \& Gross, B. L. (1991). Why we buy what we buy: A theory of consumption values. Journal of Business Research, 22, 159-170. http://dx.doi.org/10.1016/0148-2963(91)90050-8

Ulaga, W., \& Eggert, A. (2006). Relationship value and relationship quality: Broadening the homological network of business-to-business relationships. European Journal of Marketing, 40, 311-327. http://dx.doi.org/10.1108/03090560610648075

Veres, D., Clark, H., \& Golbourne, D. (2008). Increasing the contribution of special events to Niagara's tourism industry. International Journal of Contemporary Hospitality Management, 20(3), 313-319. http://dx.doi.org/10.1108/09596110810866127 
White, S. S., \& Schneider, B. (2000). Climbing the commitment ladder: The role of expectations disconfirmation on customers' behavioral intentions. Journal of Service Research, 2(3), 240-253. http://dx.doi.org/10.1177/109467050023002

Wilson, D. T. (1995). An integrated model of buyer-seller relationships. Journal of the Academy of Marketing Science, 23(4), 335-345.

$\mathrm{Wu}$, S. I. (2016). The correlation between factors in festival marketing activities, visitors' value perception and post-purchase feelings. Journal of Management and Sustainability, 6(4), 9-21.

Wu, S. I., \& Huang, L. C. (2015). The impact of physical environment and regional image on tourist's experiential values and feelings - An example of Nanzhuang area in Taiwan. International Journal of Business and Management, 10(11), 94-106. http://dx.doi.org/10.5539/ijbm.v10n11p94

Zeithaml, V. A., \& Bitner, M. J. (2000). Service marketing: Integrating customer focus across the firm. NY: McGraw-Hill.

\section{Copyrights}

Copyright for this article is retained by the author(s), with first publication rights granted to the journal.

This is an open-access article distributed under the terms and conditions of the Creative Commons Attribution license (http://creativecommons.org/licenses/by/4.0/) 